\title{
VARIABILITY OF ISOLATED COLONIES IN BEAN NODULATING RHIZOBIUM STRAINS BEFORE AND AFTER EXPOSURE TO HIGH TEMPERATURE
}

\author{
Rui Raposeiras'; Patrícia P. Pinto ${ }^{1}$; Raul V.M. Passos ${ }^{1}$; Lucy Seldin² ${ }^{2}$ Edilson Paiva ${ }^{3}$; M. Rita Scotti' ${ }^{1}$ Nadja M.H. Sá1* \\ ${ }^{1}$ Departamento de Botânica, Instituto de Ciências Biológicas, Universidade Federal de Minas Gerais, BH, Brasil; ${ }^{2}$ Instituto de \\ Microbiologia, Universidade Federal do Rio de Janeiro, Rio de Janeiro, RJ, Brasil; ${ }^{3}$ EMBRAPA, Centro Nacional de Milho e \\ Sorgo, Sete Lagoas, MG, Brasil
}

Submitted: February 21, 2001; Returned to authors for corrections: May 25, 2001; Approved: April 08, 2002

\begin{abstract}
Irregular response to bean plants to Rhizobium inoculation has been attributed to among other factors, low competitive ability, low $\mathrm{N}_{2}$ fixation efficiency and genetic instability of the symbiont. This genetic instability caused by high rates of genomic rearrangements and/or plasmid deletions can be accentuated by high temperatures. This fact may limit the utilization of these strains as inoculants, especially in tropical soils. In this study, the variability of isolated colonies derived from effective $R$. leguminosarum bv. phaseoli (SLP1.3 and BR 10.026) and $R$ tropici (SLA2.2 and BR322) strains was evaluated before and after exposure to high temperatures (four consecutive thermal shocks at $45^{\circ} \mathrm{C}$ ). This evaluation involved plant dry matter analysis of inoculated plants and genotypic (plasmid profile and genomic patterns via RAPD) analysis of the Rhizobium strains. The results evidenced that high temperature improve the natural performance variability especially between isolated colonies from $R$. leguminosarum bv. phaseoli strains. The plasmid profile of isolated colonies from $R$. tropici strains were identical regardless of temperature treatment whereas isolated colonies from $R$. leguminosarum bv. phaseoli alterations were detected especially after the thermal treatment. The genomic patterns generated by AP-PCR showed more alterations and genetic variation in isolated colonies from $R$. leguminosarum bv. phaseoli strains indicating that $R$. tropici strains are more stable and lower affected by high temperature.
\end{abstract}

Key words: Rhizobium tropici, Rhizobium leguminosarum bv. phaseoli, bean plants, high temperature, cerrado soils

\section{INTRODUCTION}

Irregular response of bean plants to Rhizobium inoculation has been attributed to, among other factors, low competitive ability, low $\mathrm{N}_{2}$ fixation efficiency and genetic instability of the symbiont. Several research laboratories have reported genetic instability of Rhizobium strains as one of the causes that compromise relevant characteristics of these organisms in the nitrogen fixation, both in wild-type strains obtained by conventional selection procedures $(13,14,17,25,26)$ and in genetically improved strains $(3,29)$. Rhizobium strains capable of nodulating bean display particular genetic characteristics that favor such instability. The genes responsible for nodulation and $\mathrm{N}_{2}$ fixation in these Rhizobium strains are localized on a single replicon, the symbiotic plasmid (pSym). The genome of Rhizobium is complex and contains several reiterated DNA sequences $(6,9,12)$. The reiterated copies are usually necessary for the expression and effectiveness of the $\mathrm{N}_{2}$ fixation $(5,9,12)$; they also provide sites for recombination that can give rise to genomic rearrangements at high rates $(12,20)$, resulting in alterations on the original characteristics of the cells (5). High temperatures can accentuate this instability enabling genomic

\footnotetext{
* Corresponding author. Mailing address: Universidade Federal de Minas Gerais, Instituto de Ciências Biológicas, Departamento de Botânica, Pampulha.
} 31270-901 - Belo Horizonte, MG, Brasil. Phone: (+5531) 499-2688 - Fax: (+5531) 499-2673. E-mail: nadja@mono.icb.ufmg.br 
rearrangements and plasmid deletions $(9,22)$, thus jeopardizing the utilization of these strains as inoculants, especially in tropical soils. In this study, isolated colonies derived from effective $R$. leguminosarum bv. phaseoli (SLP 1.3 and BR 10.026) and $R$. tropici (SLA 2.2 and BR 322) strains were evaluated before and after exposure to high temperatures. This evaluation involved both dry matter analysis of inoculated plants and genotypic (plasmid profile and genomic patterns via RAPD) analysis of the Rhizobium strains.

\section{MATERIALS AND METHODS}

\section{Obtention of isolated colonies from original Rhizobium leguminosarum bv. phaseoli (SLP 1.3 and BR 10.026) and Rhizobium tropici (SLA 2.2 and BR 322) cultures before and after exposure to a high temperature}

Ten colonies from each original strain were selected randomly in YMA (24). Then, standard liquid cultures (YM, 21) of each colony $\left(10^{8}\right.$ cells $\left./ \mathrm{ml}\right)$ were inoculated in sterilized soil $(0.7 \mathrm{ml}$ of inoculum $/ g$ soil). In the first experiment the inoculated soil was incubated at $45^{\circ} \mathrm{C}$ for 4 hours. This procedure was repeated four times within intervals of 48 hours and at the end of the fourth shock the inoculated soil was poured into plates containing YMA medium. The second experiment was done with soil inoculated with the same colonies, not subjected to high temperature. The experiments were performed in 4 repetitions. The colonies from both experiments were grown and stored at $4^{\circ} \mathrm{C}$ for further utilization in plant tests and genetic characterization studies. BR 10.026 and BR 322 are commercial strains and SLP 1.3 and SLA 2.2 are native strains from Cerrado soil.

\section{Bean plant inoculation tests}

The colonies isolated previously from each of the original strains, submitted or not to high temperature, were grown in YM medium for bean plant inoculation. They were standardized for approximately $10^{8}$ cells $/ \mathrm{ml}$ and were inoculated in "Leonard jars" containing aseptically cultivated beans (cv. aporé). The experiments were carried out using four replicates of a completely randomized block design. The Leonard jars were kept in a green house in a modified $\mathrm{N}$-free nutrition solution (11) for 30 days, after which the plants were collected and dried to evaluate the dry matter, a parameter directly correlated to nitrogen fixation $(8,15,16)$.

\section{Determination of plasmid profile}

Isolated colonies were multiplied in TY medium and the plasmid profile was determined through the methodology described by Eckhardt (4) and modified by Hynes and McGregor (7).

\section{Determination of genomic patterns via AP-PCR}

Bacterial total DNA was extracted according to the method of Sá et al. (17). DNA amplification of each colony was carried out in accordance with Steindel et al. (21). Amplification reactions were carried out in a Perkin-Elmer 9600 thermocycler and consisted of 40 cycles of: denaturation $\left(94^{\circ} \mathrm{C}\right.$ for $15 \mathrm{sec}$.), anneling $\left(35^{\circ} \mathrm{C}\right.$ for $30 \mathrm{sec}$.) and extension at $72^{\circ} \mathrm{C}$ for $1 \mathrm{~min}$. and a final extension at $72^{\circ} \mathrm{C}$ for $7 \mathrm{~min}$. Each reaction was performed in $25.0 \mathrm{ml}$ using: $2.5 \mathrm{mM} \mathrm{MgCl}_{2}, 10.0 \mathrm{mM}$ TrisHCl, $0.05 \mathrm{mM}$ each dNTP, 1.0U Taq DNA polymerase, $0.4 \mathrm{mM}$ primer and 5.0ng DNA. The following primers from the Operon Kit (Operon Technologies, Inc.) were tested: OPAC 10 (5'GGCGAGTGTG3'), OPAC 04 (5'GTCGGTTTGTC3') and primer S34 (5'GGT TCG ATT GGG GGT TGG TGT AAT ATA3'). After the AP-PCR reaction the products were electrophoretically separated on $5 \%$ polyacrylamide gels. The gels were silver stained (17) and photographed. The DNA bands were scored as present or absent. Only bands with good resolution were considered. These data were used to determine the pairwise genetic distances among the isolated colonies in relation to the original strains according to the UPGMA method (Unweighted Pair-Group Average) using the statistics Program Copyright Statsoft Inc 1995-CNMN06/74.

\section{RESULTS AND DISCUSSION}

The dry matter of plants inoculated with the different isolated colonies of R. tropici (BR322 and SLA 2.2) and R. leguminosarum bv. phaseoli (SLP 1.3 and BR 10.026) strains before and after exposure to consecutive thermal shocks was evaluated. A decrease in dry matter of plants inoculated with colonies from original R. leguminosarum bv. phaseoli SLP 1.3 strain exposed to high temperature was observed (Table 1). The dry matter was significantly different in the plants inoculated with colonies 7 and 10. When compared among themselves the ten colonies isolated from the original SLP 1.3 culture, submitted to the thermal shock, displayed a great variability in dry matter yield of plants inoculated, unlike what was observed in the ten colonies isolated from this strain, not subjected to the thermal treatment (Tukey 5\%). Exposure of isolated colonies from BR 10.026 strain to $45^{\circ} \mathrm{C}$ caused alteration in dry matter in plants inoculated with three out of the ten isolates (Tukey 5\%) - Table 1. The dry matter was lower in plants inoculated with colonies 9 and 10 and higher in those inoculated with colony 4. Although there was variation in dry matter both in plants inoculated with colonies submitted or not to high temperature, such variation was more noticeable in plants in which the inoculating colonies were subjected to the thermal treatment. In addition the average dry matter of plants inoculated with isolated colonies from $R$. leguminosarum (SLP 1.3 and BR 10.026) submitted to thermal shock was also lower than that of the control plants inoculated with original strains.

Of the two R. tropici strains tested, the BR 322 strain seemed to be less affected by temperature. According to Table 1, the SLA 2.2 strain showed significant differences in dry weight of 
Table 1. Dry matter of bean plants inoculated with isolated colonies of $R$. leguminosarum bv. phaseoli and $R$. tropici strains before and after exposure to high temperature.

\begin{tabular}{|c|c|c|c|c|c|c|c|c|c|c|c|}
\hline \multicolumn{12}{|c|}{ Isolated colonies number } \\
\hline \multirow[t]{2}{*}{$\begin{array}{l}\text { Rhizobium } \\
\text { strain }\end{array}$} & $\begin{array}{l}\text { Exposure } \\
\text { to high }\end{array}$ & 1 & 2 & 3 & 4 & 5 & 6 & 7 & 8 & 9 & 10 \\
\hline & temperature & \multicolumn{10}{|c|}{ Dry matter (mg/plant) } \\
\hline \multirow{4}{*}{$\begin{array}{l}\text { R.tropici } \\
\text { SLA2. } 2\end{array}$} & & & & & & & & & & & \\
\hline & A & $326.7^{\mathrm{bcd}}$ & $* 380.3^{\mathrm{abc}}$ & $337.5^{\mathrm{abcd}}$ & $327.5^{\text {bcd }}$ & $500.8^{\mathrm{a}}$ & $312.0^{\mathrm{cd}}$ & $511.8^{\mathrm{a}}$ & $* 171.8^{\mathrm{d}}$ & $221.7^{\mathrm{cd}}$ & $265.0^{\text {cd }}$ \\
\hline & B & $203.0^{\mathrm{ab}}$ & $* 165.5^{\mathrm{ab}}$ & $356.7^{\mathrm{a}}$ & $213.7^{\mathrm{ab}}$ & $424.8^{\mathrm{a}}$ & $285.2^{\mathrm{ab}}$ & $328.8^{\mathrm{a}}$ & $* 106.0^{\mathrm{b}}$ & $295.0^{\mathrm{ab}}$ & $176.7^{\mathrm{ab}}$ \\
\hline & $\mathrm{C}$ & 287.0 & & & & & & & & & \\
\hline \multirow[t]{3}{*}{ BR322 } & A & $207.8^{\mathrm{a}}$ & $289.0^{\mathrm{ab}}$ & $366.2^{\mathrm{a}}$ & $231.7^{\mathrm{a}}$ & $357.8^{\mathrm{a}}$ & $309.8^{\mathrm{a}}$ & $301.7^{\mathrm{a}}$ & $296.7^{\mathrm{a}}$ & $362.7^{\mathrm{a}}$ & $330.5^{\mathrm{a}}$ \\
\hline & B & $234.8^{\mathrm{bc}}$ & $300.3^{\mathrm{abc}}$ & $431.8^{\mathrm{a}}$ & $249.0^{\mathrm{bc}}$ & $414.8^{\mathrm{a}}$ & $326.7 \mathrm{abc}$ & $384.7^{\mathrm{ab}}$ & $243.0^{\mathrm{bc}}$ & $212.2^{\mathrm{c}}$ & $278.5^{\mathrm{abc}}$ \\
\hline & $\mathrm{C}$ & 299.0 & & & & & & & & & \\
\hline \multicolumn{12}{|c|}{ R. leguminosarum bv. phaseoli } \\
\hline \multirow[t]{3}{*}{ SLP1.3 } & A & $295.0^{\mathrm{a}}$ & $295.0^{\mathrm{a}}$ & $288.0^{\mathrm{a}}$ & $263.0^{\mathrm{a}}$ & $308.0^{\mathrm{a}}$ & $275.0^{\mathrm{a}}$ & $* 283.0^{\mathrm{a}}$ & $273.0^{\mathrm{a}}$ & $265.0^{\mathrm{a}}$ & $* 255.0^{\mathrm{a}}$ \\
\hline & $\mathrm{B}$ & $253.0^{\mathrm{abc}}$ & $193.0^{\mathrm{bc}}$ & $275.0^{\mathrm{ab}}$ & $297.0^{\mathrm{a}}$ & $268.0^{\mathrm{ab}}$ & $270.0^{\mathrm{ab}}$ & $* 188.0^{\mathrm{bc}}$ & $227.0^{\mathrm{abc}}$ & $303.0^{\mathrm{a}}$ & $* 170.0^{\mathrm{c}}$ \\
\hline & $\mathrm{C}$ & 302.0 & & & & & & & & & \\
\hline \multirow[t]{3}{*}{ BR10026 } & A & $228.0^{\mathrm{bc}}$ & $242.0^{\mathrm{bc}}$ & $280.0^{\mathrm{bc}}$ & $* 243.0^{\mathrm{bc}}$ & $240.0^{\mathrm{bc}}$ & $267.0^{\mathrm{bc}}$ & $310.0^{\mathrm{ab}}$ & $212.0^{\mathrm{c}}$ & $* 400.0^{\mathrm{a}}$ & $* 288.0^{\mathrm{bc}}$ \\
\hline & B & $260.0^{\mathrm{ab}}$ & $273.0^{\mathrm{ab}}$ & $208.0^{\mathrm{ab}}$ & $* 298.0^{\mathrm{ab}}$ & $198.0^{\mathrm{ab}}$ & $337.0^{\mathrm{a}}$ & $250.0^{\mathrm{ab}}$ & $262.0^{\mathrm{ab}}$ & $* 170.0^{\mathrm{b}}$ & $* 210.0^{\mathrm{b}}$ \\
\hline & $\mathrm{C}$ & 252.0 & & & & & & & & & \\
\hline
\end{tabular}

- A - Inoculated plants with isolated colonies before exposure to high temperature; B - Inoculated plants with isolated colonies after exposure to high temperature; C - Control plants inoculated with original strains;

*- Significant differences (Tukey 5\% probability) values between before and after high temperature exposure;

$\mathrm{a}, \mathrm{b}, \mathrm{c}, \mathrm{d}$ - Mean values followed by the same letters not significantly different (Turkey $5 \%$ probability) within the colonies group before or after high temperature;

- The values given (plant dry matter) represent of mean data of 4 repetitions.

the plants inoculated with colonies 2 and 8 (Tukey 5\%). Significant differences were also noticed in the productivity of plants inoculated within each group of colonies subjected or not to thermal stress. Nevertheless, average production in plants inoculated with the colonies subjected to thermal shock was lower than the average production of those not subjected to this treatment and similar to that of the control plants inoculated with original strain. Differences in dry matter yield were not observed when plants inoculated with colonies from BR 322 strain subjected to high temperature were compared to those inoculated with colonies not subjected to this treatment or to control plants inoculated with the original strain. On the other hand, the variability of the results obtained with plants inoculated with the group of colonies which underwent the thermal treatment was apparently greater and was reflected in the statistically significant differences in the values of dry matter of the plants.

The results presented above confirm the reports that high temperature may alter symbiotic characteristics of Rhizobium strains $(2,10)$. It was also noticed that temperature enhanced variability in nitrogen fixation efficacy naturally found within Rhizobium strains $(17,26)$ and that such effect varied according to the Rhizobium strains. The BR 10.026, SLP 1.3 (R. leguminosarum bv. phaseoli) and SLA 2.2 (R. tropici) were apparently more affected by this factor than the BR 322 strain (R. tropici).

Plasmid profiles of colonies from R. tropici (BR 322 and SLA 2.2) strains were identical to the original strain regardless of the temperature treatment, as shown for BR 322 in Fig. 1(i). As for the profiles of colonies from the R. leguminosarum bv. phaseoli (BR 10.026 and SLP 1.3) strains, alterations were detected after the thermal shocks. As shown by colonies from the BR 10.026 original strain Fig. 1(ii), there was plasmid loss in two colonies without the thermal stress and in eight colonies after exposure to high temperature. Plasmid profiles of the original SLP 1.3 strain and those derived from it were identical when not submitted to the temperature treatment. However, after the heat shock one band was missing in the derived colonies when compared to the original SLP 1.3 strain (data not shown).

Although reports on the instability of the Rhizobium strains that nodulate bean plants are common, it has been difficult to detect alterations utilizing solely plasmid profile data. Rhizobium strains are able to maintain their plasmids after being exposed to temperatures about $44^{\circ} \mathrm{C}$ as evidenced in $R$. leguminosarum bv. trifolii (1). On the other hand, total or partial losses of cryptic plasmids (plasmids with unknown functions) do not always compromise $\mathrm{N}_{2}$ biological fixation; and there are reports on 
A

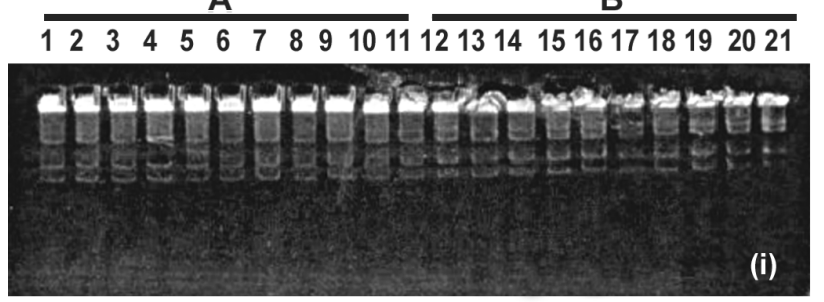

A

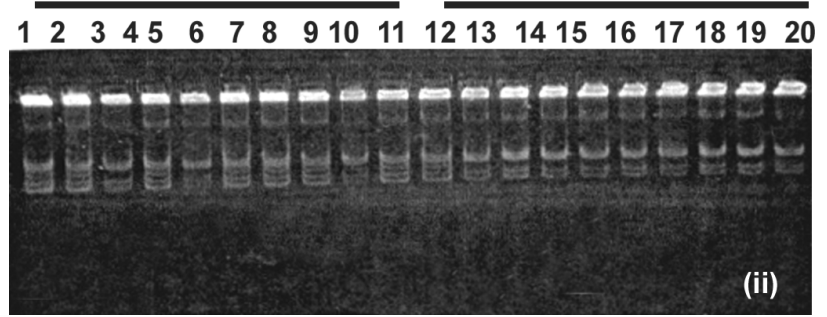

Figure 1. Plasmid profiles of isolated colonies before (A) and after (B) exposure to high temperature. (i) Rhizobium tropici BR322;1 = original strain, 2 to $11=$ isolated colonies (A) and 12 to $21=$ isolated colonies (B). (ii) Rhizobium leguminosarum BR10026; $1=$ original strain, 2 to $10=$ isolated colonies (A) and 11 to $20=$ isolated colonies (B).
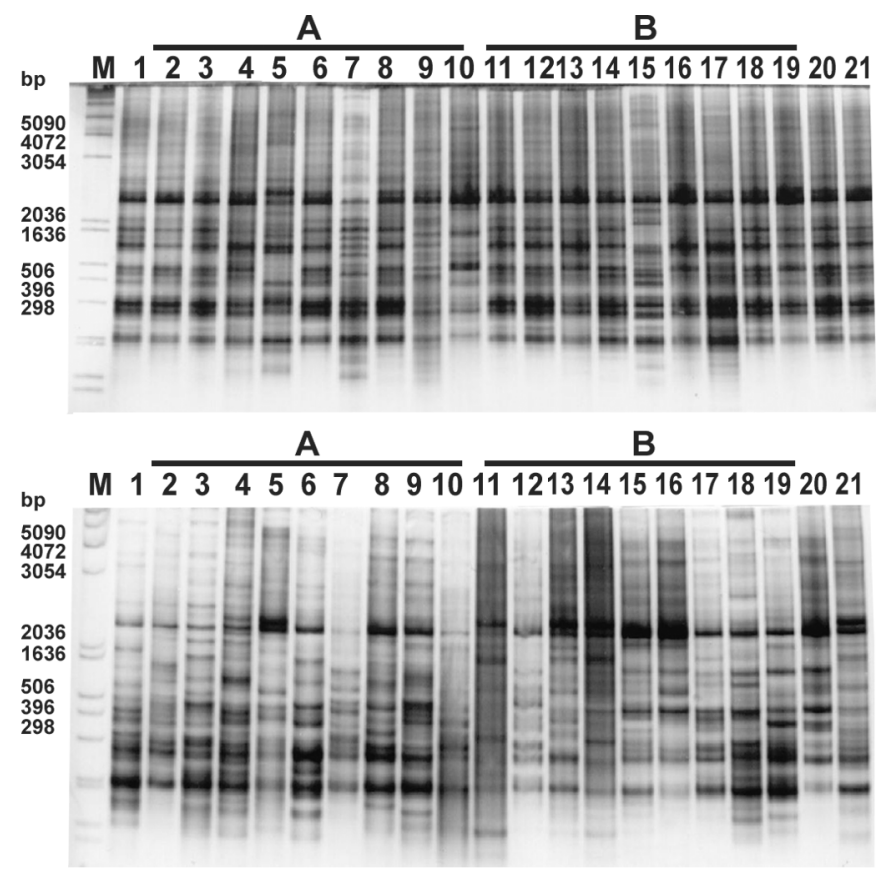

Figure 2. Amplifications of genomic DNA of isolated colonies before (A) and after (B) exposure to high temperature. M - DNA marker (1Kb ladder, BRL), (i) Rhizobium tropici SLA2.2; $1=$ original strain, 2-11= isolated colonies (A) and 12-21= isolated colonies (B) (ii) Rhizobium leguminosarum SLP1.3; 1= original strain, 2-11= isolated colonies (A) and 12-21= isolated colonies (B).
Table 2. Average variation in AP-PCR profiles of ten colonies isolated from Rhizobium sp strains, before (A) and after (B) high temperature exposure, with three different primers.

\begin{tabular}{lccc}
\hline \multirow{2}{*}{$\begin{array}{c}\text { Rhizobium } \\
\text { strains }\end{array}$} & primer & \multicolumn{2}{c}{$\begin{array}{c}\text { Percent of disagreement in } \\
\text { relation to original strains }\end{array}$} \\
\cline { 3 - 4 } R. tropici & & $\mathrm{A}$ & $\mathrm{B}$ \\
& & & \\
BR322 & OPC10 & 0.26 & 0.28 \\
& OPC04 & 0.27 & 0.30 \\
& S30 & 0.24 & 0.27 \\
& $\mathrm{X}$ & 0.26 & 0.28 \\
SLA2.2 & OPC10 & 0.28 & 0.30 \\
& OPC04 & 0.30 & 0.32 \\
& S30 & 0.28 & 0.28 \\
& $\mathrm{X}$ & 0.29 & 0.30 \\
\hline R. leguminosarum bv. phaseoli & & \\
BR10026 & OPC10 & 0.21 & 0.32 \\
& OPC04 & 0.21 & 0.34 \\
& S30 & 0.29 & 0.37 \\
& X & 0.24 & 0.34 \\
SLP1.3 & OPC10 & 0.34 & 0.42 \\
& OPC04 & 0.32 & 0.41 \\
& S30 & 0.33 & 0.38 \\
& $\mathrm{X}$ & 0.33 & 0.40 \\
\hline
\end{tabular}

Rhizobium strains that had their $\mathrm{N}_{2}$ fixation ability actually increased after elimination of some of these plasmids $(19,23)$.

Therefore, genotypic alterations that would reflect in phenotypic changes in Rhizobium strains capable of nodulating bean seem to originate especially from genomic rearrangements within specific areas of the genome; otherwise they could be due to small deletions not detectable through traditional plasmid visualization techniques or the use of specific DNA probes $(20,25)$. In this sense, the effects of high temperature on potential genetic changes in these organisms were analyzed using the AP-PCR method (Artbitrarily Primed Polymerase Chain Reaction), described by Welsh and McClelland (27). According to these authors and Williams et al. (28), this methodology allows not only identification of bacterial strains such as in other conventional methods of DNA analysis, but also allows the detection of modifications at the nucleotide level as evidenced by alterations in the number of amplified segments. Thus AP-PCR provides an useful tool in the study of genetic variation among organisms.

The analysis of the genomic patterns generated by APPCR showed alterations for all colonies after they had been exposed to high temperature. However, colonies derived from the $R$. tropici strains seemed to be less affected than the $R$. leguminosarum bv. phaseoli strains, as shown in Figs. 2(i) and 2(ii) with the SLA 2.2 (R. tropici) and SLP $1.3(R$. 
leguminosarum bv. phaseoli) strains. The rates of genetic variation average (Table 2) obtained for colonies before and after exposure to high temperature in relation to the original strains were higher for $R$. leguminosarum bv. phaseoli strains, ranging from 0.24 to 0.34 (BR 10.026) and 0.33 to 0.40 (SLP 1.3). The $R$. tropici strains showed lower genetic variation rates: 0.26 to 0.28 (BR 322) and 0.29 to 0.30 (SLA 2.2). This genetic variation, enhanced by high temperature, affected on response of plant inoculation. The alterations of plant dry matter were especially observed in inoculated plants with the isolated colonies of $R$. leguminosarum bv. phaseoli strains submitted to high temperature. Furthermore, these results confirm the high genetic instability among the Rhizobium species capable of nodulating bean plants and the greater stability of the $R$. tropici strains shown by other authors and in our previous works (14). These results allow us to recommend especially the use of strains of $R$. tropici in the production of commercial inoculants for bean grown in tropical soil.

\section{ACKNOWLEGMENTS}

The authors wish to thank Dr. Ivo Baldani (EMBRAPA/ CNPAB) for his assistance in development of plasmid methodology. The work was supported by FAPEMIG and CNPq.

\section{RESUMO}

\section{Variabilidade de colônias isoladas de estirpes de Rhizobium efetivas na nodulação do feijoeiro, antes de após exposição temperatura elevada}

A irregularidade de resposta do feijoeiro à inoculação com rizóbio tem sido atribuída, entre outros fatores, à baixa capacidade competitiva, baixa eficiência em fixar $\mathrm{N}_{2} \mathrm{e}$ instabilidade genética do simbionte. Esta instabilidade genética decorrente de frequências elevadas de rearranjos genômicos e/ ou deleções plasmidiais pode ser acentuada após exposição a temperaturas elevadas, comprometendo a utilização dessas estirpes como inoculantes, especialmente nos solos tropicais. Nesse estudo, foi avaliada a variabilidade de colônias isoladas derivadas de estirpes efetivas de $R$. leguminosarum bv. phaseoli (SLP1.3 e BR10.026) e R. tropici (SLA2.2 e BR322), antes e após exposição à temperatura elevada (4 choques térmicos sucessivos a $45^{\circ} \mathrm{C}$ ). Essa avaliação foi efetuada através da análise de características fenotípicas (medida pela produção de matéria seca das plantas inoculadas) e genotípicas (perfil plasmidial e padrões genômicos via RAPD). Os resultados obtidos indicaram que à temperatura elevada acentuou a variabilidade na performance natural entre as colônias isoladas das estirpes testadas, especialmente da espécie $R$. leguminosarum bv. phaseoli. Os perfis plasmidiais das colônias derivadas das estirpes de $R$. tropici antes e após exposição à temperatura elevada apresentaram-se idênticos entre si e em relação a estirpe original. Os padrões genômicos determinados via RAPD mostraram mais alterações e variação genética nas colônias isoladas das estirpes de $R$. leguminosarum bv. phaseoli, indicando que as estirpes de $R$. tropici são mais estáveis e foram menos afetadas pela ação da temperatura.

Palavras-chave: Rhizobium tropici, Rhizobium leguminosarum bv. phaseoli, feijoeiro, solos de cerrado, temperatura elevada.

\section{REFERENCES}

1. Baldani, J.I.; Weaver, R.; Hynes, M.F.; Eardly, B.D. Utilization of carbon substrates, electrophoretic enzyme patterns and symbiotic performance of plasmid-cured clover Rhizobia. Appl. Environ. Microbiol., 58: 2308-2314, 1992.

2. Barbour, W.M.; Elkan, G.H. Relationship of the presence and copy number of plasmids to exopolysaccharide production on symbiotic effectiveness in Rhizobium fredii USDA 206. Appl. Environ Microbiol., 55: 813-818, 1989.

3. Corich, V.; Bosco, F.; Giacomini, A.; Basaglia, M. Squartini and Nuti, M.P. Fate of genetically modified Rhizobium leguminosarum biovar viciae during long. Term storage of commercial inoculates. J. Appl. Bacteriol., 81: 319-328, 1996.

4. Eckhardt, T. A rapid method for identification of plasmid deoxyribonucleic acid in bacteria. Plasmid, 1: 584-588, 1978.

5. Flores, M.; González, V.; Pardo, M.A.; Leija, A.; Martinez, E.; Romero, D.; Pinero, P.; D’Ávila, G.; Palacios, R. Genomic instability in Rhizobium phaseoli. J. Bacteriol., 170: 1191-1196, 1988.

6. Girard, M.L.; Flores, M.; Brom, S.; Romero, D.; Palacios, R.; D'Ávila, G. Structural complexity of the symbiotic plasmid of Rhizobium leguminosarum bv. phaseoli. J. Bacteriol., 173: 24112419, 1991.

7. Hynes, M.F.; Mc Gregor, N.F. Two plasmids other than the nodulation plasmid are necessary for formation of nitrogen-fixing nodules by Rhizobium leguminosarum. Microbiol.,4: 567-574, 1990.

8. Ibrahim, M.A.; Mannetje, L't. Compatibility, persistence and productivity of grass-legume mixtures in the humid tropics of Costa Rica. 1. Dry matter yield, nitrogen yield and botanical composition. Tropical Grass., 32: 96-104, 1998.

9. Martinez, E.; Romero, D.; Palacios, R. The Rhizobium genome. Crit. Rev. Plant Sci., 9: 59-93, 1990.

10. Mathis, J.N.; Barbour, W.M.; Elkas, G.H. Effect of symbiotic plasmid during on symbiotic effetiveness in Rhizobium fredii. Appl. Environ. Microbiol., 49: 1385-1388, 1985.

11. Norris, D.O. Techniques used in work Rhizobium. In: Norris, D.O. (ed). Some Concepts and Methods in Sub-Tropical Pasture Research. Farmham Royal, London: Bucks, Commonwelth Agriculture Bureaux, 1964, p.186-19.

12. Palacios, R.; Castilho, M.; Flores, M.; Hernandez, G.; Mavingui, P.; Romero, D. Dynamics of the Rhizobium genome. In: Tikhonovich, I.A.; Provorov, N.A.; Romanov, V.I.; Newton, W.E. (eds.). Nitrogen fixation; fundamentals and application. Dordrecht, Kluwer Academic Publishers, 1995, p.353-357.

13. Peres, J.R.R.; Vargas, M.A.T.; Suhet, A.R. Variabilidade na eficiência em fixar nitrogênio entre isolados de uma mesma estirpe de Rhizobium japonicum. Rev. Bras. Ciên. Solo., 8: 193-196, 1984.

14. Pinto, P.P.; Raposeiras, R.; Macedo, A.M.; Seldin, L.; Paiva, E.; Sá, N.M.H. Effects of high temperature on survival, symbiotic performance and genomic modifications of bean nodulating Rhizobium strains. Rev. Microbiol., 29: 295-300, 1998.

15. Pinto, P.P. Ocorrência, eficiência de fixação de nitrogênio e variabilidade genética de estirpes de rizóbio associadas ao Arachis pintoi em solos de Cerrado. Minas Gerais, 2000, 93p. (Ms. Thesis. Instituto de Ciências Biológicas. UFMG). 
16. Rossum, D.V.; Muyotcha, A.; Verseveld, H.W.V.; Stouthamer, A.H.; Boogerd, F.C. Effects of Bradyrhizobium strain and host genotype, nodule dry weight and leaf area on groundnut (Arachis hypogaea L. ssp. Fastigiata) yield. Plant Soil., 154: 279-288, 1993.

17. Sá, N.M.H.; Scott, M.R.M.L.; Paiva, E.; Franco, A.A.; Dobereiner, J.; Selection and characterization of Rhizobium sp. stains stable and capable in fixing nitrogen in bean (Phaseolus vulgaris L.). Rev. Microbiol., 24: 38-48, 1993.

18. Santos, F.R.; Pena, S.D.J.; Eppelen, J.T. Genetic and population study of a y-linked tetranucleotide repeat DNA polymorphism with a simple non-isotopic technique. Hum. Gen., 90: 655-656, 1993.

19. Selbitshka, W.; Lotz, W. Instability of cryptic plasmids affect the symbiotic effectivity of Rhizobium leguminosarum bv. viciae strains. Molec. Plant Microbe Interactions, 4: 608-618,1991.

20. Soberon-Chaves, G.; Nágera, R.; Oliveira, H.; Segovia, L. Genetic rearrangements of a Rhizobium phaseoli symbiotic plasmid. J. Bacteriol., 487-491, 1986.

21. Steindel, M.; Dias Neto, E.; Meneses, C.L.P.; Romanha, A.; Simpson, A.L.G. Random amplified polymorphic DNA analisys of trypanosoma cruzi strains. Molec. Biochem. Parasitol., 60: 71-80, 1993.
22. Trevors, J.T. Plasmid curing in bacteria. FEMS Microbiol. Reviews, 32: 149-157, 1986.

23. Velazquez, E.; Mateos, P.F., Pedrero, P.; Dazzo, F.B.; MartinezMolina, E. Attenuation of symbiotic effectiveness by Rhizobium melitoli SAF22 related to the presence of a cryptic plasmid. Appl. Environ. Microbiol., 61: 2033-2036, 1995.

24. Vincent, J.M.A. Manual for the Practical Study at Root-nodule bacteria. Blackwell, Oxford, 1970, 164p.

25. Weaver, E.W.; Berryhill, D.J. Stability of plasmids in Rhizobium phaseoli during culture. Soil Biol. Biochem., 22: 465-469, 1990

26. Weaver, R.W.; Wright, S.F. Variability in effectiveness of rhizobia during culture and in nodules. Appl. Environ. Microbiol., 53: 29722974, 1987.

27. Welsh, J.; McClelland, M. Fingerprinting genome using PCR with arbitrarily primers. Nucl. Ac. Res., 18: 7213-7218, 1990

28. Williams, J.G.K.; Kubelik, A.R.; Livak, K.J.; Rafalski, J.A.; Scott, V.T. DNA polymorphisms amplified by arbitrarily primers are useful as genetic markers. Nucl. Ac. Res., 18: 6531-6535, 1990.

29. Wilson, M.; Lindow, S.E. Release of recombinant microorganisms. Ann. Rev. Microbiol., 47: 913-944, 1993. 